\title{
A Risk-Return Analysis of Loan Portfolio Diversification in the Vietnamese Banking System*
}

\author{
Japan HUYNH', Van Dan DANG ${ }^{2}$
}

Received: June 26, 2020 Revised: July 12, 2020 Accepted: August 10, 2020

\begin{abstract}
The study empirically examines the effects of loan portfolio diversification on bank risk and return in the nascent banking market of Vietnam. Loan portfolio diversification is captured through the Hirschman-Herfindahl index and the Shannon Entropy with sectoral exposures. We access each bank's financial reports to collect the required data, especially the breakdown of sectoral loan portfolios, thus constituting a unique dataset. To compute bank return, we use the traditional accounting indicators, including return-on-assets, return-on-equity, and net-interest margin. For bank risk, we utilize the loan-loss provisions and non-performing loans relative to gross customer loans. Using a sample of 30 commercial banks over the period from 2008 to 2019 and the system generalized method of moments estimator for the dynamic panel, we indicate the downsides of portfolio diversification. Concretely, we observe that all diversification measures exhibit significantly negative signs in all regressions across different bank return proxies. At the same time, the estimates display the significant and positive impact of diversification on the non-performing loan ratio. Hence, sectoral loan portfolio diversification significantly hampers bank performance in both aspects of lower return and higher credit risk. The results are robust across a rich set of bank performance and portfolio diversification measures.
\end{abstract}

Keywords: Bank Return, Bank Risk, Diversification, Loan Portfolio, Vietnam

JEL Classification Code: G11, G21, G28

\section{Introduction}

Over the years, the banking industries around the world have experienced considerable changes. Financial integration and competition have led banks to expand and diversify their loan portfolios. However, the problem is whether loan portfolio diversification across different economic sectors is detrimental or beneficial to bank performance.

\footnotetext{
*Acknowledgements:

This paper is part of the doctoral thesis by Japan Huynh at the Banking University of Ho Chi Minh City, under the supervision of Associate Professor Van Dan Dang.

${ }^{1}$ First Author and Corresponding Author. PhD Student, Department of Postgraduate, Banking University of Ho Chi Minh City, Vietnam [Postal Address: 36 Ton That Dam Street, Nguyen Thai Binh Ward, District 1, Ho Chi Minh City 700000, Vietnam] Email: japanhuynh@gmail.com

${ }^{2}$ Lecturer, Department of Finance, Banking University of Ho Chi Minh City, Vietnam. Email: dandv@buh.edu.vn

(c) Copyright: The Author(s)

This is an Open Access article distributed under the terms of the Creative Commons Attribution Non-Commercial License (https://creativecommons.org/licenses/by-nc/4.0/) which permits unrestricted non-commercial use, distribution, and reproduction in any medium, provided the original work is properly cited.
}

The implication of such diversification has been extensively revealed for developed markets, but no consensus has been obtained thus far (Acharya, Hasan, \& Saunders, 2006; Behr, Kamp, Memmel, \& Pfingsten, 2007; Hayden, Porath, \& Westernhagen, 2007; Jahn, Memmel, \& Pfingsten, 2013; Rossi, Schwaiger, \& Winkler, 2009; Shim, 2019). The prior works indicate both the bright side and dark side of loan portfolio diversification. In this stream, only a few papers investigate the banking systems in large emerging countries and also suggest mixed patterns (Chen, Shi, Wei, \& Zhang, 2014; Tabak, Fazio, \& Cajueiro, 2011). In comparison, the banking system in small emerging markets exhibits numerous variations from those in advanced and large emerging countries, in the form of the mature levels and regulatory backgrounds. So, the implications of the previous studies might not well apply to these small emerging markets.

This study aims to empirically explore the impacts of sectoral loan portfolio diversification on bank return and risk in Vietnam. As far as we know, our work is the first to examine the portfolio diversification/return and risk nexus in a small emerging economy like Vietnam. With the unique features, Vietnam supplies a favorable context to analyze the present topic. The integration of the economy 
in 2007 after Vietnam joined the World Trade Organization (WTO) has paved the way for the financial liberalization that boosted foreign banks' entry and altered the manner that Vietnamese banks operate. Increasing competition in the banking system has encouraged banks to diversify their asset portfolios (Dang, 2019; Vo, 2016). Banks have provided loans to various sectors, even the ones that they were not familiar with before. Moreover, after going through significant reforms recently, the banking system in Vietnam is also encouraged by the regulatory authorities to diversify their loan portfolios, avoiding concentrating on lending to one or a few sectors. However, the critical question that loan portfolio diversification benefits or hampers bank performance has been left unaddressed.

To achieve our research objectives, we employ a sample of 30 commercial banks in Vietnam from 2008 to 2019. We access each bank's financial reports to collect required data, especially the breakdown of sectoral loan portfolios, thus constituting a unique dataset. To ensure the robustness of the results, we construct a rich set of measures for bank diversification, return, and risk. Empirical estimations are carried out by the system generalized method of moments (GMM) estimator for the dynamic panel. These econometric profiles are expected to yield reliable findings in this study.

Our work contributes to the existing banking literature in at least two main ways. First, we fill the literature gap on the linkage between loan portfolio diversification and bank performance in terms of both bank profitability and risk using the data from a small emerging market. So far, this research strand has mostly focused on developed economies (such as the US and Europe) or leading emerging markets (China and Brazil) due to the banking industries' rich datasets. Second, we provide a better understanding of sectoral loan portfolio diversification by a number of accounting ratios for bank risk and return. In this regard, the consideration of the net interest margin in our econometric model of the Shannon Entropy index has been neglected in earlier documents. Based on our settings, we expect to offer more insight into the hot debate in Vietnam and other emerging markets, where many naive banks are now interested in the portfolio diversification strategy.

The rest of this paper is organized as follows. Section 2 reviews the related literature on the current topic. Section 3 presents the methodology and data needed to obtain the research objectives. Section 4 reports and discusses the estimation results. Section 5 concludes and offers insightful implications.

\section{Literature Review}

Theories identify two main routes through which loan portfolio diversification can influence bank performance. According to the traditional banking theory, diversifying loan portfolios across different economic sectors could help banks mitigate the probability of bankruptcy due to the idiosyncratic shocks (Berger, Hasan, \& Zhou, 2010). Besides, well-diversified banks may benefit from reduced asymmetric information, leading to lower financial intermediation costs (Diamond, 1984). Furthermore, in practice, policymakers and practitioners have recently blamed portfolio concentration for causing financial crises, implying the high riskiness of this lending strategy.

This study aims to empirically explore the impacts of sectoral loan portfolio diversification on bank return and risk in Vietnam. As far as we know, our work is the first to examine the portfolio diversification/return and risk nexus in a small emerging economy like Vietnam. With the unique features, Vietnam supplies a favorable context to analyze the present topic. The integration of the economy in 2007 after Vietnam joined the World Trade Organization (WTO) has paved the way for the financial liberalization that boosted foreign banks' entry and altered the manner that Vietnamese banks operate. Increasing competition in the banking system has encouraged banks to diversify their asset portfolios (Dang, 2019; Vo, 2016). Banks have provided loans to various sectors, even the ones that they were not familiar with before. Moreover, after going through significant reforms recently, the banking system in Vietnam is also encouraged by the regulatory authorities to diversify their loan portfolios, avoiding concentrating on lending to one or a few sectors. However, the critical question that loan portfolio diversification benefits or hampers bank performance has been left unaddressed.

Many empirical studies have been conducted to shed light on the linkage between loan portfolio diversification and bank performance in both profitability and risk aspects. Most of them pay attention to developed economies. In their seminal paper, Acharya et al. (2006) utilize a sample of 105 Italian banks during the period 1993-1999 to find the answer. The authors suggest the diseconomies of diversification in the form of higher risk (stock return volatility and doubtful loans) and lower return (ROA and stock return). In sharp contrast, Rossi et al. (2009) reveal multiple gains of bank diversification across industries, through a dataset of the 100 largest banks from 1997 to 2003 in Austria. More precisely, their analysis displays that portfolio diversification mitigates loan loss provisions and improves profit efficiency. Among European countries, Germany is the one that attracts the most attention from academics. Behr et al. (2007), Hayden et al. (2007), and Jahn et al. (2013) compare the benefits of specialization versus diversification in the German banking market for different periods. The authors all conclude that specialized banks outperform diversified banks in terms of gaining higher profitability and suffering lower credit risks. Nevertheless, a significant shortcoming of the studies conducted using the data of Germany is that they adopt the fixed effects regressions in static panels, which is subject to 
a reverse causality issue. A risky bank may decide to focus its loan portfolio on the sectors less exposed to risk. Most recently, Shim (2019) studies how the diversification of loan activities affects banks' financial stability. Taking the data of the US commercial banks, the author claims that increased loan diversification exerts a positive effect on banks' financial strength, thus supporting the bright side of diversification.

While a large body of documents examines the impacts of loan portfolio diversification on bank risk and return in developed markets, a few papers address this link for banks in emerging markets. We are only aware of the related work of Chen et al. (2014) and Tabak et al. (2011) in this context. Using monthly data of 96 Brazilian banks from 2003 to 2009, Tabak et al. (2011) find that loan portfolio concentration significantly improves bank performance in both aspects of higher return and lower default risk. Not supporting the comprehensive benefit view of loan portfolio diversification like Tabak et al. (2011), Chen et al. (2014) suggest a risk-return trade-off instead. Concretely, analyzing 16 listed commercial banks in China from 2007 to 2011, Chen et al. (2014) show that sectoral diversification decreases bank return and alleviates bank risk simultaneously. Overall, the role of loan portfolio diversification in emerging markets has still been inconclusive empirically.

\section{Methodology and Data}

\subsection{Variables}

\subsubsection{Portfolio Diversification Measures}

This study employs two sets of measures to alternatively assess the level of loan portfolio diversification in the Vietnamese banking system. In line with most studies done on the present topic (e.g., Acharya et al., 2006; Berger et al., 2010; Chen et al., 2014; Rossi et al., 2009; Tabak et al., 2011), we first approach the Hirschman-Herfindahl index (HHI) that is written as follows:

$$
H H I_{i t}=1-\sum_{s=1}^{n} x_{s i t}^{2}
$$

where $x_{\text {sit }}$ is the relative exposure of the bank $i$ at time $t$ to the economic sector $s$, calculated by the ratio of loans to each sector to total gross customer loans. We should note that the higher value of the HHI measure implies a higher level of diversification.

Next, we consider the Shannon Entropy (SE) as an effective instrument to indicate the diversification of sectoral loan portfolios. It is used in some works by Behr et al. (2007) and Tabak et al. (2011). The formula can be specified as follows:

$$
S E_{i t}=\sum_{s=1}^{n} x_{s i t} \times \ln \left(\frac{1}{x_{s i t}}\right)
$$

The SE measure ranges from 0 to $\ln (n)$. The former indicates a perfect specialized portfolio, while the latter exhibits a perfect diversified portfolio.

Vietnamese banks during the sample period did not display uniform styles in classifying the sectors of loan portfolios. So, to overcome this challenge, we follow the strategy of Acharya et al. (2006) to adopt a disaggregated sectoral decomposition with a total of the top six sectoral exposures, in which the sixth exposure highlights the sum of the all remaining exposures. Furthermore, to determine whether this approach is sensitive to the choice of the number of sectoral exposures, we continue to behave similarly for the scenarios of eight and ten sectoral exposures. This procedure could check the robustness of our findings.

\subsubsection{Bank Return and Risk Measures}

To measure bank return, we use the traditional accounting indicators, namely, return-on-assets $(R O A)$ and return-onequity $(R O E)$. These indicators are commonly considered in the banking literature (Dao \& Nguyen, 2020; Ha, 2020; Tuan, 2020). Furthermore, enriching the extant literature strand, we take into account a supplementary indicator that indicates the capacity of generating interest income - net interest margin (NIM), calculated by the ratio of net interest income to total average interest-earning assets. This study is the first to examine the linkage between loan portfolio diversification and net interest margin.

Given that there has been no consensus on the best indicator of bank risk, in this case, we approach bank credit risk, which is the most important type of risk an intermediary could face. We employ loan loss provisions and non-performing loans as shares of gross customer loans to constitute our measures for bank risk. These are also the most commonly used measures in the banking literature to denote the repayment capacity of borrowers (NPL) and banks' coverage to handle potential lending losses ( $L L P)$. The greater values of these measures suggest a higher risk level. Overall, the application of multiple return and risk measures could offer a comprehensive understanding of the portfolio diversification/bank performance link that we are exploring.

\subsubsection{Control Variables}

Our analysis belongs to the literature stream on the determinants of bank return and risk. Based on the findings obtained previously, we include some key control factors that well explain bank profit-making and risk-taking behavior. In this regard, we select bank capital, bank size and liquidity positions, computed by the ratio of equity capital to total assets, the natural logarithm of total assets, and the ratio of liquid assets (cash plus interbank deposits) to total assets, respectively. For more details on the rationale of using these 
variables as controls in the function of bank profit and risk, see Batten and Vo (2019), Dang (2019), Dao and Nguyen (2020), and Delis, Hasan, and Tsionas (2014).

\subsection{Model Specification and Regression Method}

The study builds on the works highlighting the dynamic nature of bank performance to explore the importance of loan portfolio diversification. Therefore, we specify the model specification as follows:

$$
\begin{aligned}
Y_{i, t}=\alpha_{0} & +\alpha_{1} \times Y_{i, t-1}+\alpha_{2} \times \text { Diversification }_{i, t-1} \\
& +\alpha_{3} \times Z_{i, t-1}+\varepsilon_{i, t}
\end{aligned}
$$

where $Y$ is either the measure of bank return $(R O A, R O E$, and NIM) or bank risk (LLP and NPL). Diversification is the measure of loan portfolio diversification based on the HHI and SE. $Z$ is a vector of control variables as mentioned above and $\varepsilon$ is the error term. We incorporate the lagged dependent variable into the right-hand side of the equation to adopt the dynamic profile that indicates the persistence in bank risk and return, in line with former findings (Berger, Bonime, Covitz, \& Hancock, 2000; Delis et al., 2014; Goddard, Liu, Molyneux, \& Wilson, 2011; Levonian, 1994). We take oneyear lags of all independent variables to (i) mitigate the endogeneity problem and (ii) support the notion that banking decisions take time to occur.

To appropriately estimate ourdynamic model specification, we apply the GMM estimator (Arellano \& Bover, 1995;
Blundell \& Bond, 1998). This estimator could well tackle the endogeneity issue by using the lags of regressors in levels and first differences as internal instruments. To ensure the consistency of our results, we confine the proliferation of instruments following the procedure of Roodman (2009). Ultimately, to justify the usage of the GMM estimator, we perform the Hansen test (for the validity of the instrument set) and the Arrelano-Bond test (for the absence of the second-order autocorrelation in residuals).

\subsection{Data}

The study utilizes the data of commercial banks in Vietnam from 2008 to 2019. The data obtained via annual financial reports of each bank must ensure the detailed breakdown of sectoral loan portfolios for at least five consecutive years, which fits the research objectives and enhances the estimates' reliability. We do not consider banks that are acquired or under special control by the government due to their distinctive operation regimes and these banks do not have enough observations as well. Due to missing data, our sample ends up with an unbalanced panel, including 30 banks and covering about $90 \%$ of the total assets of the Vietnamese banking industry. To neutralize the impacts of extreme outliers, we winsorize the variables constructed using the sample dataset at the interval of $2.5 \%$ and $97.5 \%$.

We present the summary statistics of all variables used in Table 1. Over the 2008-2019 sample period, the level of loan portfolio diversification is relatively high, e.g., the average

\begin{tabular}{|c|c|c|c|c|c|c|}
\hline Variables & Definitions & Obs & Mean & SD & Min & Max \\
\hline \multicolumn{7}{|c|}{ Portfolio diversification measures } \\
\hline $\mathrm{HHI} 10$ & HHI diversification measure based on each bank's top 10 sectoral exposures & 259 & 0.77 & 0.08 & 0.58 & 0.87 \\
\hline SE10 & SE diversification measure based on each bank's top 10 sectoral exposures & 259 & 1.77 & 0.30 & 1.10 & 2.16 \\
\hline HHI8 & HHI diversification measure based on each bank's top 8 sectoral exposures & 259 & 0.76 & 0.08 & 0.58 & 0.86 \\
\hline SE8 & SE diversification measure based on each bank's top 8 sectoral exposures & 259 & 1.70 & 0.26 & 1.10 & 2.01 \\
\hline $\mathrm{HHI6}$ & HHI diversification measure based on each bank's top 6 sectoral exposures & 259 & 0.75 & 0.07 & 0.58 & 0.82 \\
\hline SE6 & SE diversification measure based on each bank's top 6 sectoral exposures & 259 & 1.55 & 0.18 & 1.10 & 1.74 \\
\hline \multicolumn{7}{|c|}{ Return measures } \\
\hline NIM & net interest income/total average interest-earning assets & 356 & 3.87 & 1.31 & 1.84 & 6.53 \\
\hline ROA & net return/total average assets & 356 & 0.90 & 0.64 & 0.04 & 2.24 \\
\hline ROE & net return/total average equity & 356 & 9.82 & 7.06 & 0.68 & 25.56 \\
\hline \multicolumn{7}{|c|}{ Risk measures } \\
\hline NPL & non-performing loans/total gross loans & 318 & 2.20 & 1.21 & 0.60 & 5.63 \\
\hline LLP & Ioan loss provisions/total gross loans & 356 & 1.26 & 0.47 & 0.66 & 2.45 \\
\hline \multicolumn{7}{|c|}{ Control factors } \\
\hline Capital & equity capital/total assets & 356 & 9.95 & 4.59 & 4.92 & 21.51 \\
\hline Liquidity & liquid assets/total assets & 356 & 16.85 & 8.96 & 5.42 & 35.86 \\
\hline Size & the natural logarithm of total assets & 356 & 18.23 & 1.23 & 16.21 & 20.49 \\
\hline
\end{tabular}

Table 1: Summary statistics 
values of HHI10 and SE10 equal to 0.77 and 1.77 , respectively. Additionally, observing the statistical distribution of measures for bank return and risk, we realize the considerable fluctuation in the performance among banks in Vietnam, illustrated by the high standard deviation and the wide range of extreme values. So, enough heterogeneity in the research sample will support the efficiency of estimates in this study.

\section{Results and Discussion}

Before entering the detailed estimates, we need to pay attention to the diagnostic tests for the GMM estimator in all regressions. The Hansen test offers no evidence against the validity of the set of instruments selected, and the AR(2) test verifies that there exists no second-order autocorrelation. Unsurprisingly, there is significant persistence of our dependent variables with all bank return and risk measures. Hence, the combination of all these results justifies the approach by the dynamic GMM model in this study.

\subsection{Loan Portfolio Diversification and Bank Return}

Tables 2 to 4 report the regression results for bank return. We could observe that all diversification measures exhibit significantly negative signs in all regressions across different bank return proxies. These findings strongly suggest that sectoral loan diversification is detrimental to Vietnamese banks' profitability, consistent with the conclusions of Acharya et al. (2006) and Tabak et al. (2011). Complementing their works, our analysis confirms the downside of portfolio diversification in terms of net interest margin, which has remained unexplored thus far.

Table 2: Regression results for bank return by return on assets

\begin{tabular}{|c|c|c|c|c|c|c|}
\hline Variables & (1) ROA & (2) ROA & (3) ROA & (4) ROA & (5) ROA & (6) ROA \\
\hline \multirow[t]{2}{*}{ Lagged dependent variable } & $0.783^{* * *}$ & $0.781^{* * *}$ & $0.771^{* * *}$ & $0.792^{* * *}$ & $0.787^{* * *}$ & $0.777^{* * *}$ \\
\hline & $(0.023)$ & $(0.024)$ & $(0.024)$ & $(0.026)$ & $(0.026)$ & $(0.026)$ \\
\hline \multirow[t]{2}{*}{$\mathrm{HHI} 10$} & $-1.083^{* * *}$ & & & & & \\
\hline & $(0.178)$ & & & & & \\
\hline \multirow[t]{2}{*}{$\mathrm{HHI} 8$} & & $-1.139^{* * *}$ & & & & \\
\hline & & $(0.185)$ & & & & \\
\hline \multirow[t]{2}{*}{$\mathrm{HHI6}$} & & & $-1.382^{* * *}$ & & & \\
\hline & & & $(0.220)$ & & & \\
\hline \multirow[t]{2}{*}{ SE10 } & & & & $-0.216^{* * *}$ & & \\
\hline & & & & $(0.043)$ & & \\
\hline \multirow[t]{2}{*}{ SE8 } & & & & & $-0.265^{\star * *}$ & \\
\hline & & & & & $(0.050)$ & \\
\hline \multirow[t]{2}{*}{ SE6 } & & & & & & $-0.416^{* * *}$ \\
\hline & & & & & & $(0.072)$ \\
\hline \multirow[t]{2}{*}{ Size } & $0.055^{\star * *}$ & $0.055^{* * *}$ & $0.058^{* * *}$ & $0.051^{* * *}$ & $0.053^{* * *}$ & $0.054^{* * *}$ \\
\hline & $(0.015)$ & $(0.016)$ & $(0.017)$ & $(0.016)$ & $(0.016)$ & $(0.017)$ \\
\hline \multirow[t]{2}{*}{ Capital } & $0.009^{*}$ & $0.009^{*}$ & $0.010^{* \star}$ & 0.008 & 0.008 & $0.009^{*}$ \\
\hline & $(0.005)$ & $(0.005)$ & $(0.005)$ & $(0.005)$ & $(0.005)$ & $(0.005)$ \\
\hline \multirow[t]{2}{*}{ Liquidity } & -0.002 & -0.002 & -0.001 & -0.003 & -0.002 & -0.001 \\
\hline & $(0.003)$ & $(0.003)$ & $(0.003)$ & $(0.003)$ & $(0.003)$ & $(0.003)$ \\
\hline Observations & 231 & 231 & 231 & 231 & 231 & 231 \\
\hline Banks & 30 & 30 & 30 & 30 & 30 & 30 \\
\hline Instruments & 25 & 25 & 25 & 25 & 25 & 25 \\
\hline $\mathrm{AR}(1)$ test & 0.008 & 0.008 & 0.008 & 0.008 & 0.009 & 0.009 \\
\hline$A R(2)$ test & 0.344 & 0.344 & 0.355 & 0.298 & 0.298 & 0.305 \\
\hline Hansen test & 0.155 & 0.156 & 0.152 & 0.166 & 0.169 & 0.168 \\
\hline
\end{tabular}

Notes: The table reports the results regressed by the two-step system GMM estimator for the dynamic panel. The explanatory variables of main interest are portfolio diversification measures, based on the Hirschman-Herfindahl index (HHI) and the Shannon Entropy (SE). The tests for the GMM estimator are presented with p-values. Standard errors are shown in parentheses and ${ }^{*},{ }^{* *}$, and ${ }^{* * *}$ denotes significance levels at $10 \%, 5 \%, 1 \%$, respectively. 
Table 3: Regression results for bank return by return on equity

\begin{tabular}{|c|c|c|c|c|c|c|}
\hline Variables & (1) ROE & (2) ROE & (3) ROE & (4) ROE & (5) ROE & (6) ROE \\
\hline \multirow[t]{2}{*}{ Lagged dependent variable } & $0.863^{\star * *}$ & $0.859^{* * *}$ & $0.851^{* * *}$ & $0.875^{* * *}$ & $0.870^{* * *}$ & $0.862^{* * *}$ \\
\hline & $(0.035)$ & $(0.035)$ & $(0.036)$ & $(0.030)$ & $(0.031)$ & $(0.034)$ \\
\hline \multirow[t]{2}{*}{ HHI10 } & $-8.377^{* * *}$ & & & & & \\
\hline & $(2.245)$ & & & & & \\
\hline \multirow[t]{2}{*}{$\mathrm{HHI} 8$} & & $-9.034^{* * *}$ & & & & \\
\hline & & $(2.319)$ & & & & \\
\hline \multirow[t]{2}{*}{ HHI6 } & & & $-11.071^{* * *}$ & & & \\
\hline & & & $(2.800)$ & & & \\
\hline \multirow[t]{2}{*}{ SE10 } & & & & $-1.527^{* * *}$ & & \\
\hline & & & & $(0.530)$ & & \\
\hline \multirow[t]{2}{*}{ SE8 } & & & & & $-1.992^{* * *}$ & \\
\hline & & & & & $(0.624)$ & \\
\hline \multirow[t]{2}{*}{ SE6 } & & & & & & $-3.335^{* * *}$ \\
\hline & & & & & & $(0.981)$ \\
\hline \multirow[t]{2}{*}{ Size } & 0.335 & 0.356 & 0.382 & 0.212 & 0.249 & 0.301 \\
\hline & $(0.292)$ & $(0.296)$ & $(0.301)$ & $(0.268)$ & $(0.278)$ & $(0.291)$ \\
\hline \multirow[t]{2}{*}{ Capital } & -0.065 & -0.063 & -0.059 & $-0.080^{*}$ & -0.077 & -0.070 \\
\hline & $(0.049)$ & $(0.049)$ & $(0.048)$ & $(0.047)$ & $(0.047)$ & $(0.047)$ \\
\hline \multirow[t]{2}{*}{ Liquidity } & $-0.041^{*}$ & $-0.040^{*}$ & -0.036 & $-0.046^{\star *}$ & $-0.043^{*}$ & -0.038 \\
\hline & $(0.022)$ & $(0.023)$ & $(0.023)$ & $(0.022)$ & $(0.023)$ & $(0.024)$ \\
\hline Observations & 231 & 231 & 231 & 231 & 231 & 231 \\
\hline Banks & 30 & 30 & 30 & 30 & 30 & 30 \\
\hline Instruments & 25 & 25 & 25 & 25 & 25 & 25 \\
\hline$A R(1)$ test & 0.027 & 0.027 & 0.027 & 0.028 & 0.028 & 0.028 \\
\hline $\mathrm{AR}(2)$ test & 0.686 & 0.679 & 0.662 & 0.773 & 0.769 & 0.750 \\
\hline Hansen test & 0.225 & 0.224 & 0.216 & 0.232 & 0.227 & 0.222 \\
\hline
\end{tabular}

Notes: The table reports the results regressed by the two-step system GMM estimator for the dynamic panel. The explanatory variables of main interest are portfolio diversification measures, based on the Hirschman-Herfindahl index (HHI) and the Shannon Entropy (SE). The tests for the GMM estimator are presented with p-values. Standard errors are shown in parentheses and *, ${ }^{* *}$, and ${ }^{* * *}$ denotes significance levels at $10 \%, 5 \%, 1 \%$, respectively. 
Table 4: Regression results for bank return by net interest margin

\begin{tabular}{|c|c|c|c|c|c|c|}
\hline Variables & (1) NIM & (2) NIM & (3) NIM & (4) NIM & (5) NIM & (6) NIM \\
\hline \multirow[t]{2}{*}{ Lagged dependent variable } & $0.711^{* * *}$ & $0.708^{\star \star *}$ & $0.700^{* * *}$ & $0.718^{\star * *}$ & $0.712^{* * *}$ & $0.708^{* * *}$ \\
\hline & $(0.034)$ & $(0.033)$ & $(0.032)$ & $(0.033)$ & $(0.032)$ & $(0.030)$ \\
\hline \multirow[t]{2}{*}{ HHI10 } & $-1.266^{* * *}$ & & & & & \\
\hline & $(0.428)$ & & & & & \\
\hline \multirow[t]{2}{*}{$\mathrm{HHI} 8$} & & $-1.386^{\star * *}$ & & & & \\
\hline & & $(0.457)$ & & & & \\
\hline \multirow[t]{2}{*}{ HHI6 } & & & $-1.829^{* * *}$ & & & \\
\hline & & & $(0.579)$ & & & \\
\hline \multirow[t]{2}{*}{ SE10 } & & & & $-0.229^{* *}$ & & \\
\hline & & & & $(0.116)$ & & \\
\hline \multirow[t]{2}{*}{ SE8 } & & & & & $-0.315^{\star *}$ & \\
\hline & & & & & $(0.135)$ & \\
\hline \multirow[t]{2}{*}{ SE6 } & & & & & & $-0.553^{* * *}$ \\
\hline & & & & & & $(0.199)$ \\
\hline \multirow[t]{2}{*}{ Size } & 0.019 & 0.022 & 0.028 & 0.007 & 0.012 & 0.021 \\
\hline & $(0.036)$ & $(0.036)$ & $(0.038)$ & $(0.033)$ & $(0.034)$ & $(0.035)$ \\
\hline \multirow[t]{2}{*}{ Capital } & 0.004 & 0.005 & 0.008 & 0.000 & 0.002 & 0.005 \\
\hline & $(0.013)$ & $(0.013)$ & $(0.013)$ & $(0.012)$ & $(0.013)$ & $(0.013)$ \\
\hline \multirow[t]{2}{*}{ Liquidity } & $0.012^{* * *}$ & $0.012^{* * *}$ & $0.013^{* * *}$ & $0.012^{* * *}$ & $0.012^{* * *}$ & $0.013^{* * *}$ \\
\hline & $(0.003)$ & $(0.003)$ & $(0.003)$ & $(0.003)$ & $(0.003)$ & $(0.003)$ \\
\hline Observations & 231 & 231 & 231 & 231 & 231 & 231 \\
\hline Banks & 30 & 30 & 30 & 30 & 30 & 30 \\
\hline Instruments & 25 & 25 & 25 & 25 & 25 & 25 \\
\hline$A R(1)$ test & 0.005 & 0.005 & 0.005 & 0.005 & 0.005 & 0.006 \\
\hline$A R(2)$ test & 0.702 & 0.694 & 0.671 & 0.737 & 0.724 & 0.702 \\
\hline Hansen test & 0.379 & 0.382 & 0.383 & 0.360 & 0.370 & 0.390 \\
\hline
\end{tabular}

Notes: The table reports the results regressed by the two-step system GMM estimator for the dynamic panel. The explanatory variables of main interest are portfolio diversification measures, based on the Hirschman-Herfindahl index (HHI) and the Shannon Entropy (SE). The tests for the GMM estimator are presented with p-values. Standard errors are shown in parentheses and ${ }^{*},{ }^{* *}$, and ${ }^{* * *}$ denotes significance levels at $10 \%, 5 \%, 1 \%$, respectively. 
With respect to economic significance, our results are also reasonable. Taking the first column in all three tables for an example, we infer that an increase of one standard deviation in HHI10 (0.08) might cause a reduction in $R O A$ by 0.087 $(1.083 \times 0.08)$ percentage points, $R O E$ by $0.670(8.377 \times 0.08)$ percentage points, and NIM by $0.101 \quad(1.266 \times 0.08)$ percentage points. Given the distribution of these return measures reported in Table 1, we gain substantial evidence that sectoral loan diversification hampers bank profits.

Multiple mechanisms could interpret our findings. First, when expanding loans to sectors in which banks may lack expertise and experience, it could potentially diminish the loan monitoring efficiency. This ultimately elevates the operating costs of banks. Second, in case banks increase their exposures to sectors that are heavily financed by other banks already, the adverse selection could emerge and thus mitigate the quality of loan portfolios. Moreover, the high level of competition in sectoral segments may force banks to cut lending rates to attract customers, which does not benefit the sources of bank interest income. Third, diversification can multiply bank size, thus leading to scale inefficiencies.

\subsection{Loan Portfolio Diversification and Bank Risk}

We now move on to the estimation results for bank risk reported in Tables 5 and 6 . In Table 5, we do not find the statistically significant impact of diversification measures on the loan loss provision ratio. However, Table 6 displays the significant and positive impact of diversification on the non-performing loan ratio in many columns (in some detail, columns 1-3 with all HHI measures and column 6 with one SE measure). Our findings firmly indicate that sectoral

Table 5: Regression results for bank return by loan loss provisions

\begin{tabular}{|c|c|c|c|c|c|c|}
\hline Variables & (1) LLP & (2) LLP & (3) LLP & (4) LLP & (5) LLP & (6) LLP \\
\hline \multirow[t]{2}{*}{ Lagged dependent variable } & $0.625^{* * *}$ & $0.624^{* * *}$ & $0.622^{* * *}$ & $0.626^{* * *}$ & $0.626^{* * *}$ & $0.624^{* * *}$ \\
\hline & $(0.035)$ & $(0.035)$ & $(0.037)$ & $(0.033)$ & $(0.033)$ & $(0.036)$ \\
\hline \multirow[t]{2}{*}{$\mathrm{HHI} 10$} & -0.034 & & & & & \\
\hline & $(0.094)$ & & & & & \\
\hline \multirow[t]{2}{*}{$\mathrm{HHI} 8$} & & -0.024 & & & & \\
\hline & & $(0.099)$ & & & & \\
\hline \multirow[t]{2}{*}{$\mathrm{HHI} 6$} & & & 0.031 & & & \\
\hline & & & $(0.127)$ & & & \\
\hline \multirow[t]{2}{*}{ SE10 } & & & & -0.023 & & \\
\hline & & & & $(0.021)$ & & \\
\hline \multirow[t]{2}{*}{ SE8 } & & & & & -0.020 & \\
\hline & & & & & $(0.024)$ & \\
\hline \multirow[t]{2}{*}{ SE6 } & & & & & & -0.000 \\
\hline & & & & & & $(0.040)$ \\
\hline \multirow[t]{2}{*}{ Size } & 0.002 & 0.001 & 0.001 & 0.003 & 0.003 & 0.001 \\
\hline & $(0.007)$ & $(0.007)$ & $(0.007)$ & $(0.007)$ & $(0.007)$ & $(0.007)$ \\
\hline \multirow[t]{2}{*}{ Capital } & $-0.012^{* * *}$ & $-0.012^{* * *}$ & $-0.012^{* * *}$ & $-0.012^{* * *}$ & $-0.012^{* * *}$ & $-0.012^{* * *}$ \\
\hline & $(0.002)$ & $(0.002)$ & $(0.002)$ & $(0.002)$ & $(0.002)$ & $(0.002)$ \\
\hline \multirow[t]{2}{*}{ Liquidity } & 0.002 & 0.002 & 0.002 & 0.002 & 0.002 & 0.002 \\
\hline & $(0.002)$ & $(0.002)$ & $(0.002)$ & $(0.002)$ & $(0.002)$ & $(0.002)$ \\
\hline Observations & 231 & 231 & 231 & 231 & 231 & 231 \\
\hline Banks & 30 & 30 & 30 & 30 & 30 & 30 \\
\hline Instruments & 25 & 25 & 25 & 25 & 25 & 25 \\
\hline$A R(1)$ test & 0.000 & 0.000 & 0.000 & 0.000 & 0.000 & 0.000 \\
\hline$A R(2)$ test & 0.913 & 0.912 & 0.906 & 0.917 & 0.916 & 0.909 \\
\hline Hansen test & 0.573 & 0.572 & 0.573 & 0.580 & 0.578 & 0.577 \\
\hline
\end{tabular}

Notes: The table reports the results regressed by the two-step system GMM estimator for the dynamic panel. The explanatory variables of main interest are portfolio diversification measures, based on the Hirschman-Herfindahl index (HHI) and the Shannon Entropy (SE). The tests for the GMM estimator are presented with p-values. Standard errors are shown in parentheses and ${ }^{*},{ }^{* *}$, and ${ }^{* * *}$ denotes significance levels at $10 \%, 5 \%, 1 \%$, respectively. 
loan portfolio diversification does not assure a decline in bank credit risk. More importantly, we even gain evidence that banks suffer the deterioration in the quality of loan portfolios.

The research results once again support the works of Acharya et al. (2006) and Tabak et al. (2011) obtained for the banking industries in Italia and Brazil, but contradict the view that diversification reduces bank risk suggested by Chen et al. (2014) for the Chinese market, which shares multiple similarities with the Vietnamese banking industry. Our obtained patterns are relevant to the Vietnamese banking system, where features the operation of nascent commercial banks. These banks are easily subject to decreased monitoring efficiency when diversifying into multiple sectors. They are incapable of catching problematic loans before these items deteriorate, thus rising credit risk.
To gauge the economic significance, we utilize the estimated coefficients in the sixth column (Table 6). The estimate implies that a one standard deviation increase in SE6 (0.18) leads to an increase in credit risk captured by $N P L$ of $0.088(0.491 \times 0.18)$ percentage points. Given that the average value of is $N P L 2.2 \%$, this specific interpretation highlights the economic plausibility of our results.

Regarding the estimation results for control variables, some consistent and significant patterns have also appeared. We observe that bank size positively affects bank return and negatively drives bank risk, which means that larger banks could benefit from economies of scale (Chortareas, Girardone, \& Ventouri, 2012; Pasiouras \& Kosmidou, 2007; Tan \& Floros, 2013). Next, we find bank capital to be negatively correlated with bank risk, implying that higher capital buffers improve bank credit quality.

Table 6: Regression results for bank return by non-performing loans

\begin{tabular}{|c|c|c|c|c|c|c|}
\hline Variables & (1) NPL & (2) NPL & (3) NPL & (4) NPL & (5) NPL & (6) NPL \\
\hline \multirow[t]{2}{*}{ Lagged dependent variable } & $0.378^{* * *}$ & $0.378^{* * *}$ & $0.378^{* * *}$ & $0.382^{* * *}$ & $0.383^{* * *}$ & $0.384^{* * *}$ \\
\hline & $(0.029)$ & $(0.029)$ & $(0.028)$ & $(0.031)$ & $(0.030)$ & $(0.029)$ \\
\hline \multirow[t]{2}{*}{$\mathrm{HHI} 10$} & $1.146^{* *}$ & & & & & \\
\hline & $(0.515)$ & & & & & \\
\hline \multirow[t]{2}{*}{$\mathrm{HHI} 8$} & & $1.240^{* *}$ & & & & \\
\hline & & $(0.547)$ & & & & \\
\hline \multirow[t]{2}{*}{ HHI6 } & & & $1.530^{* *}$ & & & \\
\hline & & & $(0.722)$ & & & \\
\hline \multirow[t]{2}{*}{ SE10 } & & & & 0.198 & & \\
\hline & & & & $(0.123)$ & & \\
\hline \multirow[t]{2}{*}{ SE8 } & & & & & $0.265^{*}$ & \\
\hline & & & & & $(0.150)$ & \\
\hline \multirow[t]{2}{*}{ SE6 } & & & & & & $0.491^{* *}$ \\
\hline & & & & & & $(0.243)$ \\
\hline \multirow[t]{2}{*}{ Size } & $-0.260^{* * *}$ & $-0.260^{\star * *}$ & $-0.260^{* * *}$ & $-0.250^{* * *}$ & $-0.253^{\star \star \star}$ & $-0.258^{* \star *}$ \\
\hline & $(0.039)$ & $(0.039)$ & $(0.039)$ & $(0.039)$ & $(0.039)$ & $(0.039)$ \\
\hline \multirow[t]{2}{*}{ Capital } & $-0.028^{* *}$ & $-0.028^{* *}$ & $-0.028^{* *}$ & $-0.026^{*}$ & $-0.027^{*}$ & $-0.028^{* *}$ \\
\hline & $(0.014)$ & $(0.014)$ & $(0.014)$ & $(0.014)$ & $(0.014)$ & $(0.014)$ \\
\hline \multirow[t]{2}{*}{ Liquidity } & 0.007 & 0.008 & 0.008 & 0.008 & 0.008 & 0.008 \\
\hline & $(0.006)$ & $(0.006)$ & $(0.006)$ & $(0.006)$ & $(0.006)$ & $(0.006)$ \\
\hline Observations & 222 & 222 & 222 & 222 & 222 & 222 \\
\hline Banks & 30 & 30 & 30 & 30 & 30 & 30 \\
\hline Instruments & 25 & 25 & 25 & 25 & 25 & 25 \\
\hline$A R(1)$ test & 0.003 & 0.003 & 0.003 & 0.004 & 0.004 & 0.003 \\
\hline$A R(2)$ test & 0.189 & 0.189 & 0.189 & 0.188 & 0.189 & 0.188 \\
\hline Hansen test & 0.237 & 0.241 & 0.239 & 0.231 & 0.238 & 0.248 \\
\hline
\end{tabular}

Notes: The table reports the results regressed by the two-step system GMM estimator for the dynamic panel. The explanatory variables of main interest are portfolio diversification measures, based on the Hirschman-Herfindahl index (HHI) and the Shannon Entropy (SE). The tests for the GMM estimator are presented with p-values. Standard errors are shown in parentheses and ${ }^{*},{ }^{* *}$, and ${ }^{* * *}$ denotes significance levels at $10 \%, 5 \%, 1 \%$, respectively. 
Possibly, the owners of well-capitalized banks are more careful and wiser with their investment items (DemirgucKunt, Detragiache, \& Merrouche, 2013; Jacques \& Nigro, 1997).

\section{Conclusions}

Theories posit various routes through which the diversification of sectoral loan portfolios could induce an impact on bank risk and return. The direction of effect is multifaceted, so how sectoral loan portfolio diversification drives bank performance remains an important empirical question to address. Research on this issue mainly focuses on developed countries, namely the US and Europe, suggesting mixed results on the upsides and downsides of loan portfolio diversification. An in-depth analysis performed for an emerging market is expected to offer more insight into the current topic.

In this paper, we find loan portfolio diversification to be detrimental to Vietnamese banks in the sense that it reduces bank profitability and increases credit risks. Vietnamese banks generally are nascent institutions, so the lending allocation to multiple economic sectors appears to require additional costs to monitor loans, in which sometimes banks fail to deal with the deterioration. The application of the GMM estimator for the dynamic setting is fitted to yield efficient estimates. Furthermore, our findings are robust across a rich set of bank performance and portfolio diversification measures.

Some managerial and policy implications can be drawn from the findings of this paper. From the perspective of banks themselves, a specialized portfolio in sectors that banks have expertise on is acceptable since the expansion into different economic sectors without efficient monitoring could damage their overall performance. For regulators, they must be vigilant in encouraging banks to diversify their loan portfolios as this strategy seems not to guarantee an improvement in the quality of bank credit. Taken together, it is not necessary to diversify or expand lending activities if banks are not ready yet, especially nascent banks in emerging markets.

\section{References}

Acharya, V. V., Hasan, I., \& Saunders, A. (2006). Should banks be diversified? Evidence from individual bank loan portfolios. Journal of Business, 79(3), 1355-1412. https://doi. org/10.1086/500679

Arellano, M., \& Bover, O. (1995). Another look at the instrumental variable estimation of error-components models. Journal of Econometrics, 68(1), 29-51. https://doi.org/10.1016/03044076(94)01642-D

Batten, J. A., \& Vo, X. V. (2019). Determinants of bank profitability - Evidence from Vietnam. Emerging Markets Finance and
Trade, 55(6), 1417-1428. https://doi.org/10.1080/154049 6X.2018.1524326

Behr, A., Kamp, A., Memmel, C., \& Pfingsten, A. (2007). Diversification and the banks' risk-return-characteristics evidence from loan portfolios of German banks. Discussion Paper Series 2. Banking and Financial Studies, Deutsche Bundesbank,Frankfurt, Germany.

Berger, A. N., Bonime, S. D., Covitz, D. M., \& Hancock, D. (2000). Why are bank profits so persistent? The roles of product market competition, informational opacity, and regional/ macroeconomic shocks. Journal of Banking and Finance, 24(7), 1203-1235. https://doi.org/10.1016/S0378-4266(99)00124-7

Berger, A. N., Hasan, I., \& Zhou, M. (2010). The effects of focus versus diversification on bank performance: Evidence from Chinese banks. Journal of Banking and Finance, 34(7), 14171435. https://doi.org/10.1016/j.jbankfin.2010.01.010

Blundell, R., \& Bond, S. (1998). Initial conditions and moment restrictions in dynamic panel data models. Journal of Econometrics, 87(1), 115-143. https://doi.org/10.1016/S03044076(98)00009-8

Chen, Y., Shi, Y., Wei, X., \& Zhang, L. (2014). How does credit portfolio diversification affect banks' return and risk? Evidence from Chinese listed commercial banks. Technological and Economic Development of Economy, 20(2), 332-352. https:// doi.org/10.3846/20294913.2014.915246

Chortareas, G. E., Girardone, C., \& Ventouri, A. (2012). Bank supervision, regulation, and efficiency: Evidence from the European Union. Journal of Financial Stability, 8(4), 292-302. https://doi.org/10.1016/j.jfs.2011.12.001

Dang, V. D. (2019). Should Vietnamese banks need more equity? Evidence on risk-return trade-off in dynamic models of banking. Journal of Risk and Financial Management, 12(2), 1-13. https://doi.org/10.3390/jrfm12020084

Dao, B. T. T., \& Nguyen, D. P. (2020). Determinants of profitability in commercial banks in Vietnam, Malaysia and Thailand. Journal of Asian Finance, Economics, and Business, 7(4), 133143. https://doi.org/10.13106/jafeb.2020.vol7.no4.133

Dao, B. T. T., \& Nguyen, K. A. (2020). Bank capital adequacy ratio and bank performance in Vietnam: A simultaneous equations framework. Journal of Asian Finance, Economics and Business, 7(6), 39-46. https://doi.org/10.13106/jafeb.2020.vol7.no6.039

Delis, M. D., Hasan, I., \& Tsionas, E. G. (2014). The risk of financial intermediaries. Journal of Banking and Finance, 44(1), 1-12. https://doi.org/10.1016/j.jbankfin.2014.03.024

Demirguc-Kunt, A., Detragiache, E., \& Merrouche, O. (2013). Bank capital: Lessons from the financial crisis. Journal of Money, Credit and Banking, 45(6), 1147-1164. https://doi. org/10.1111/jmcb.12047

Denis, D. J., Denis, D. K., \& Sarin, A. (1997). Agency problems, equity ownership, and corporate diversification. The Journal of Finance, 52(1), 135. https://doi.org/10.2307/2329559 
Diamond, D. W. (1984). Financial intermediation and delegated monitoring. The Review of Economic Studies, 51(3), 393. https://doi.org/10.2307/2297430

Goddard, J., Liu, H., Molyneux, P., \& Wilson, J. O. S. (2011). The persistence of bank profit. Journal of Banking and Finance, 35(11), 2881-2890. https://doi.org/10.1016/j. jbankfin.2011.03.015

Ha, V. D. (2020). The impacts of empowerment on the teamwork performance: Evidence from commercial banks in Vietnam. Journal of Asian Finance, Economics, and Business, 7(4), 267273. https://doi.org/10.13106/jafeb.2020.vol7.no4.267

Hayden, E., Porath, D., \& Westernhagen, N. V. (2007). Does diversification improve the performance of German banks? Evidence from individual bank loan portfolios. Journal of Financial Services Research, 32(3), 123-140. https://doi. org/10.1007/s10693-007-0017-0

Jacques, K., \& Nigro, P. (1997). Risk-based capital, portfolio risk, and bank capital: A simultaneous equations approach. Journal of Economics and Business, 49(6), 533-547. https://doi. org/10.1016/s0148-6195(97)00038-6

Jahn, N., Memmel, C., \& Pfingsten, A. (2013). Banks' concentration versus diversification in the loan portfolio: New evidence from Germany. Discussion Papers 53/2013. Deutsche Bundesbank, Frankfurt, Germany.

Jensen, M. (1986). Agency costs of free cash flow, corporate finance, and takeovers. American Economic Review, 76, 323329.

Levonian, M. E. (1994). The persistence of bank profits: what the stock market implies. Economic Review - Federal Reserve Bank of San Francisco, 2, 3-17.
Pasiouras, F., \& Kosmidou, K. (2007). Factors influencing the profitability of domestic and foreign commercial banks in the European Union. Research in International Business and Finance, 21(2), 222-237. https://doi.org/10.1016/j. ribaf.2006.03.007

Roodman, D. (2009). How to do xtabond2: An introduction to difference and system GMM in Stata. Stata Journal, 9(1), 86136. https://doi.org/10.1177/1536867x0900900106

Rossi, S. P. S., Schwaiger, M. S., \& Winkler, G. (2009). How loan portfolio diversification affects risk, efficiency and capitalization: A managerial behavior model for Austrian banks. Journal of Banking and Finance, 33(12), 2218-2226. https://doi.org/10.1016/j.jbankfin.2009.05.022

Shim, J. (2019). Loan portfolio diversification, market structure and bank stability. Journal of Banking and Finance, 104, 103115. https://doi.org/10.1016/j.jbankfin.2019.04.006

Tabak, B. M., Fazio, D. M., \& Cajueiro, D. O. (2011). The effects of loan portfolio concentration on Brazilian banks' return and risk. Journal of Banking and Finance, 35(11), 3065-3076. https:// doi.org/10.1016/j.jbankfin.2011.04.006

Tan, Y., \& Floros, C. (2013). Risk, capital and efficiency in Chinese banking. Journal of International Financial Markets, Institutions and Money, 26(1), 378-393. https://doi. org/10.1016/j.intfin.2013.07.009

Tuan, T. T. (2020). The impact of balanced scorecard on performance: The case of Vietnamese commercial banks. Journal of Asian Finance, Economics, and Business, 7(1), 7179. https://doi.org/10.13106/jafeb.2020.vol7.no1.71

Vo, X. V. (2016). Finance in Vietnam-an overview. Afro-Asian Journal of Finance and Accounting, 6(3), 202-209. https://doi. org/10.1504/AAJFA.2016.079311 